\title{
THE EFFECTS OF SUCCESSIONAL STAGE AND SIZE OF GAPS ON RECRUITMENT OF CLONAL PLANTS IN OVERGROWING Molinietum caeruleae MEADOWS
}

\author{
Kinga Kostrakiewicz-Gierałt \\ Department of Botany, Jagiellonian University, Krakow, Lubicz 24, Poland \\ Department of Plant Ecology, Institute of Botany, Jagiellonian University \\ e-mail: kingakostrakiewicz@ tlen.pl
}

Received: 28.06.2014

\begin{abstract}
In majority of plant communities with a closed canopy, the disturbances created by abiotic factors and biotic agents contribute to origin of an area free of existing vegetation and considered as safe sites for seedling recruitment. Although the gaps are characterized by several features, the size is proposed to be the most important characteristic. The investigations of recruitment of clonal taxa in different-sized gaps were conducted in the years 2011-2012 in Molinietum caeruleae meadows representing various successional stages and dominated by different species. Patch ES, representing early-successional stage, was dominated by small meadow species, Patch MS, representing mid-successional stage, was prevailed by tall-growing macroforbs, while Patch LS representing late-successional stage was overgrown by macroforbs and willows. In the successive sites the mean height of plant canopy, as well as the period of spring inundation increased gradually.

The total number of species and seedlings decreased from the Patch ES, through the Patch MS, to the Patch LS. Almost all plants presenting positive correlation between seedling number and gap area created hypogeogenous stems with substantial lateral growth and considerable number of short-lived daughter ramets allowing the fast colonization of neighbourhood. The majority of species showing negative relationship formed epigeogenous stems with slight lateral growth, as well as low number of long-lived ramets contributing to slow colonization of area.

In light of performed studies, it might be concluded, that making disturbance in continuous plant canopy and litter might be very effective way of conservation of Molinietum caeruleae meadows. The creation of different-sized gaps seems to be especially valuable due to the maintenance of heterogeneity of clonal species, which is particularly important in advanced successional stages.
\end{abstract}

Key words: colonization of openings; disturbance; gap; meadows, life-history traits.

\section{INTRODUCTION}

In majority of semi-natural plant communities with a closed canopy, the disturbances created by abiotic (such as windstorms, floods, fires, landslides), as well as biotic factors (i.e. death of plant individuals or their parts, animal and man activities) contribute to the origin of areas free of existing vegetation and considered as safe sites for seedling recruitment [1]. Although the gaps are characterized by several features such as size, shape, micro-topography, age, season of creation and origin [2,3], the size is proposed to be the most important characteristic [4]. Until now the colonization of gaps with various size was mostly investigated in relation to seed dimensions. Such observations were carried out in wide spectrum of habitats from seminatural pastures [5], via grasslands [6] and meadows [7], to forests [8-10]. Moreover, W illia m s [11] studied the effect of gap size on recruitment of species with various growth form, while K o t a n e n [12] investigated the impact of opening area on seedling recruitment in relation to growth form and lifespan of species, as well as their mode of reproduction.

Despite of growing interest in the role of gap area on plant recruitment process the present state of knowledge is still unsatisfactory. Particularly, there is lack of investigations of natural recruitment of clonal plants with various life-history traits relevant to iterative growth and influencing the colonization abilities. The studies of regularities governing the recruitment of fast and slow colonizers are very valuable from academic point of view and also they might be crucial for nature conservation.

Taking into account the insufficient state of knowledge, the main aim of undertaken studies was 
to investigate the recruitment of clonal plants in overgrowing Molinietum caeruleae meadows The detailed goals focused on assessment of: (1) the number of species and seedlings in patches representing various successional stages, (2) the species diversity in the different-sized gaps in each patch, (3) the correlation between gap area and number of seedlings of particular species, (3) the relationship between opening size and occurrence of taxa adapted to the fast and slow clonal spread.

I hypothesized, that: (1) the species/ seedling abundance diminishes in course of succession, (2) the similar assemblages of taxa fill all gaps, (3) there is no correlations between gap area and seedling number, (4) the life-history traits relevant to clonality do not influence gap colonization.

\section{Study area}

The studies were carried out in Molinietum caeruleae meadows being one of the rapidly vanishing communities of Central Europe [13-17]. The study area, located in Kostrze (south-western part of Kraków), is a remnant of meadows extending in the past from the Niepołomice Primeval Forest to Czernichów [18-20]. In the study area three patches were established. The Patch ES, representing early-successional stage, was prevailed by small meadow taxa such as loosely tufted grasses and small rosette-forb species. The Patch MS, representing mid-successional stage, was overgrown by tall-growing macroforbs creating robust, fleshy underground organs. The Patch LS, representing late-successional stage, was dominated by macroforbs and shrub-willows (Fig. 1).

\section{MATERIALS AND METHODS}

\section{The investigations of site conditions}

In order to capture the ending of the inundation, the observations of the occurrence of stagnant water were carried out once a week from $1^{\text {st }}$ March to $30^{\text {th }}$ April in the years 2011 and 2012. The first day, in which the water table was not observed on the soil surface, was considered as the end of temporal flooding period. Each year the average height of vascular plants in each patch was evaluated on the basis of measurements of 20 randomly chosen stems of different species. The measurements were performed using a folding tape measure on 8th July 2011 and on 12th July 2012. The light intensity at the soil level was surveyed with a digital photometer Voltcraft MS-1300 (accuracy +/- 5\% + 10 digits; measuring range 0.01-50 $000 \mathrm{~lx}$ ). Each year 50 measurements per patch was performed; the half of measurements was done in the sunny days (8th July 2011 and 12th July 2012) and the others in the clouded days (28th July 2011 and 26th July 2012). The detailed description of habitat conditions is given in Table 1.

Table 1

The characteristic of site conditions in the sites dominated by small meadow species (Patch I), prevailed by tall-growing perennials (Patch II), as well as overgrown by large-tussock species and shrub-willows (Patch III).

\begin{tabular}{|c|c|c|c|}
\hline Patch & ES & MS & LS \\
\hline The patch area $\left(\mathrm{m}^{2}\right)$ & 4400 & 5600 & 9000 \\
\hline Successional stage & Early & Medium & Late \\
\hline The number of species in patch & 46 & 41 & 35 \\
\hline $\begin{array}{l}\text { The dominants (species, } \\
\text { with cover exceeding 20\%) }\end{array}$ & $\begin{array}{l}\text { Brizamedia, } \\
\text { Lychnis flos-cuculi, } \\
\text { Succisa pratensis }\end{array}$ & $\begin{array}{l}\text { Lysimachia vulgaris, } \\
\text { Filipendula ulmaria, } \\
\text { Lythrum salicaria }\end{array}$ & $\begin{array}{l}\text { Salix repens ssp. rosmarinifolia } \\
\text { Filipendula ulmaria, } \\
\text { Lythrum salicaria, Serratula tinctoria }\end{array}$ \\
\hline $\begin{array}{l}\text { The subdominants (species, } \\
\text { with cover level ranging 5-20\%) }\end{array}$ & $\begin{array}{l}\text { Leucanthemum vulgare, } \\
\text { Centaurea jacea }\end{array}$ & $\begin{array}{l}\text { Serratula tinctoria, } \\
\text { Polygonum bistorta }\end{array}$ & $\begin{array}{c}\text { Salixcinerea, Carex gracilis } \\
\text { Molinia caerulaea, } \\
\text { Deschampsia caespitosa }\end{array}$ \\
\hline $\begin{array}{l}\text { End of period of permanent water } \\
\text { stagnation in the spring } 2011\end{array}$ & 26Mar & 14Apr & 24Apr \\
\hline $\begin{array}{l}\text { End of period of permanent water } \\
\text { stagnation in the spring } 2012\end{array}$ & 29Mar & 18Apr & 28Apr \\
\hline $\begin{array}{l}\text { The mean vascular } \\
\text { plant height }(\mathrm{cm}) \text { in } 2011\end{array}$ & $36.6( \pm 16.9)$ & $79.9( \pm 22.6)$ & $146.8( \pm 44.9)$ \\
\hline $\begin{array}{l}\text { The mean vascular } \\
\text { plant height }(\mathrm{cm}) \text { in } 2012\end{array}$ & $41.9( \pm 12.3)$ & $86.7( \pm 38.9)$ & $157.6( \pm 51.2)$ \\
\hline $\begin{array}{l}\text { The mean light intensity } \\
\text { at the soil level (lx) in } 2011\end{array}$ & $\begin{array}{l}48000.0 \\
( \pm 12000)\end{array}$ & $\begin{array}{l}43000.0 \\
( \pm 11000)\end{array}$ & $\begin{array}{l}37000.0 \\
( \pm 15000)\end{array}$ \\
\hline $\begin{array}{l}\text { The mean light intensity } \\
\text { at the soil level (lx) in } 2012\end{array}$ & $\begin{array}{c}47000.0 \\
( \pm 18000)\end{array}$ & $\begin{array}{l}40000.0 \\
( \pm 21000)\end{array}$ & $\begin{array}{l}35000.0 \\
( \pm 16000)\end{array}$ \\
\hline
\end{tabular}




\section{The gap creation}

In each of aforementioned patches ten permanent experimental plots were randomly arranged on 29th April 2011. Each plot was consisted of four square-shaped, adjacent subplots measuring $0.16 \mathrm{~m}^{2}$ (subplot 1), $0.09 \mathrm{~m}^{2}$ (subplot 2), $0.04 \mathrm{~m}^{2}$ (subplot 3), and $0.01 \mathrm{~m}^{2}$ (subplot 4 ). In each subplot the aboveground plant biomass and litter layer were removed.
Such treatment is considered as an optimal for seedling establishment in the Molinietum caeruleae meadows [20]. The plots were separated from each other by at least $3.0 \mathrm{~m}$ wide belts of intact vegetation to ensure sample independency. Moreover, all plots were situated ca 2.0 metres from the border of patch to avoid edge effect. The design of experiment is given in Fig. 1.
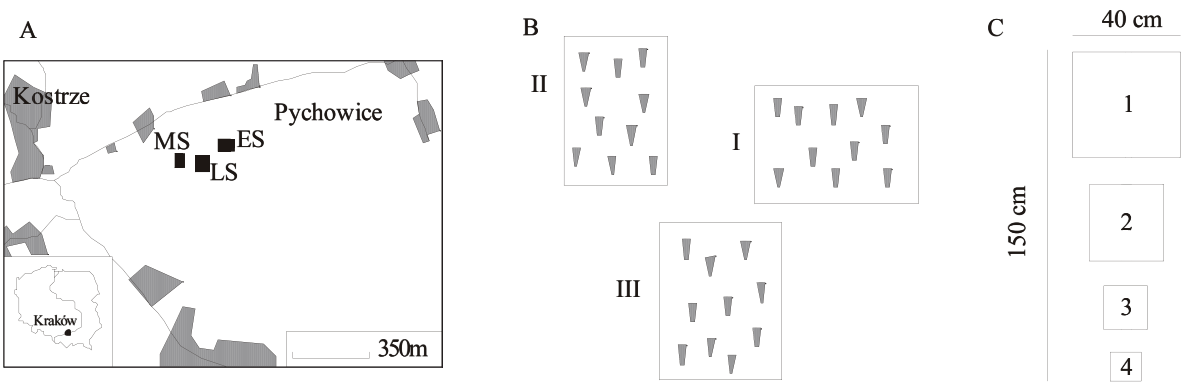

Fig. 1. The study area and experimental design.

Location of patchrepresenting early-successional stage (ES), mid-successional stage (MS), as well as late-successional stage (LS). Location of experimental plots in particular patches

Location of subplots measured $0.16 \mathrm{~m}^{2}(1), 0.09 \mathrm{~m}^{2}(2), 0.04 \mathrm{~m}^{2}(3)$, and $0.01 \mathrm{~m}^{2}(4)$ within experimental plots

\section{The observations of seedling recruitment}

The seedling recruitment was monitored once a week in May, June, July and August, and once every two weeks in September and October, in 2011 and 2012. The seedlings and saplings were removed and determined according to Cs a p odý [21] and Mulle r [22] with support of own comparative collection. The nomenclature of taxa follows Mirek et al. [23]. The genets of rare and protected plants were replanted and marked with plastic rings and sticks. The colonization of patches was characterized by mean cumulative number of species and seedlings calculated by adding species (seedlings) that appeared over the course of two years in all experimental plots. Simultaneously, the presence of particular species (with seedling numbers) in different-sized subplots was noted. In order to evaluate the correlations between opening area and seedling number the absolute cumulative numbers of seedlings of particular species noted in each subplot measuring $0.16 \mathrm{~m}^{2}, 0.09 \mathrm{~m}^{2}, 0.04 \mathrm{~m}^{2}$ and $0.01 \mathrm{~m}^{2}$ were divided by $0.16,0.09,0.04$ and 0.01 , respectively. Altogether, 40 values were computed for each species occurring in seedling pool of particular patch. Such relative, comparable values were used for evaluation of the correlation ranks. In order to estimate the influence of life history traits relevant to clonality on colonization of gaps, for each species appearing in seedling pool the values of selected features were assigned. These were: the necessary clonal growth organ (categories: horizontal above ground stems, epigeogenous stems, hypogeogenous stems, roots with adventitious buds, root-spitters), the lateral spread per year (categories: $0.01 / 0.01-0.25 />0.25 \mathrm{~m}$ ), the number of offspring per parent ramet per year (categories: $<1 / 1 / 1-10 />10$ ) and the lifespan of a shoot (categories: 1/2/>2 years). According to K li m e š o vá et al. [24] the aforementioned traits seem to be "ecologically meaningful" in managed grasslands and meadows. The information about values of life-history traits was obtained from the database CLO-PLA 3 [25,26]. For taxa capable of developing more than one type of necessary clonal growth organ or presenting different values of other traits, the most commonly noted data was incorporated in the analysis.

\section{The statistical analysis}

The normal distribution of the untransformed data was tested using the Kolmogorov-Smirnov onesample test at the significance level of $p<0.05$. Subsequently, the variance homogeneity was tested using the Brown-Forsythe test at the significance level of $p<0.05$.

As the distribution of characteristics in some groups of data was not consistent with the normal distribution and the variance was not homogeneous, the statistical analysis was based on the nonparametric tests. The H Kruskal-Wallis test was applied to examine if there were significant differences in the number of appearing taxa/seedlings between particular patches. After a significant value of test, the post-hoc comparisons were made. The statistical significance of relationship between opening size and relative numbers of seedlings of each taxa was tested with Spearman correlation co- 
efficient for each patch separately. All analyses were computed using STATISTICA software (version 10).

\section{RESULTS}

Altogether, 34 species were found in the seedling pool of the Patch ES, 33 taxa occurred in the Patch MS and 28 species appeared in the Patch LS. The average number of species per plot in Patch ES achieved 32.0 ( \pm 1.2$)$, in Patch MS it reached 28.7 ( \pm 1.9 ), while in Patch LS it amounted 24.7 ( \pm 1.1$)$. The species number differed significantly among patches $(\mathrm{H}=23.29$; $d f=2 ; \mathrm{P}<0.001)$. The greatest statistical difference at the level $\mathrm{P}<0.001$ was noted among Patches ES and LS, while among Patch ES and MS it reached $\mathrm{P}<0.05$.

In total, 4977 seedlings were appeared in whole study area. In Patch ES the average number of seedlings per plot achieved $240.0( \pm 32.4)$, in Patch MS it reached 159.8 ( \pm 35.5 ), whereas in Patch LS it amounted $97.9( \pm 22.5)$. The number of seedlings differed significantly among patches $(\mathrm{H}=23.29 ; d f=2 ; \mathrm{P}<0.001)$. The greatest statistical difference at the level $\mathrm{P}<0.001$ was found among Patches ES and LS, whereas among Patch ES and MS it amounted $\mathrm{P}<0.05$.

Table 2

The occurrence (+) and absence (-) of particular species in subplots measured $0.16 \mathrm{~m}^{2}(1), 0.09 \mathrm{~m}^{2}(2), 0.04 \mathrm{~m}^{2}(3)$, and $0.01 \mathrm{~m}^{2}$

(4), in the sites dominated by small meadow species (Patch ES), prevailed by tall-growing perennials (Patch MS), as well as overgrown by large-tussock species and shrub-willows (Patch LS in the years 2011 and 2012

\begin{tabular}{|c|c|c|c|c|c|c|c|c|c|c|c|c|}
\hline \multirow[t]{2}{*}{ Species } & \multicolumn{4}{|c|}{ Patch ES } & \multicolumn{4}{|c|}{ Patch MS } & \multicolumn{4}{|c|}{ Patch LS } \\
\hline & 1 & 2 & 3 & 4 & 1 & 2 & 3 & 4 & 1 & 2 & 3 & 4 \\
\hline Achillea millefolium $\mathrm{L}$. & + & + & + & + & + & + & + & + & + & + & + & + \\
\hline Betonica officinalis L. (Trevis) & + & + & + & + & + & + & + & + & + & + & + & + \\
\hline Caltha palustris $\mathrm{L}$. & + & + & + & + & + & + & + & + & - & - & - & - \\
\hline Centaurea jacea $\mathrm{L}$. & + & + & + & + & - & - & - & - & - & - & - & - \\
\hline Cirsium arvense (L.) Scop. & + & + & + & + & + & + & + & + & + & + & + & + \\
\hline Cirsium rivulare (Jacq.) All. & + & + & + & + & + & + & + & + & + & + & + & - \\
\hline Cruciata glabra (L.) Erhend. & + & + & + & + & + & + & + & + & + & + & + & + \\
\hline Dianthus superbus L. & + & + & + & + & - & + & - & - & - & + & - & - \\
\hline Filipendula ulmaria (L.) Maxim. & + & + & + & + & + & + & + & + & + & + & + & + \\
\hline Filipendula vulgaris Moench. & + & + & + & + & + & + & + & + & - & - & - & - \\
\hline Galium boreale L. & + & + & + & + & + & + & + & + & + & + & + & + \\
\hline Galium verum $\mathrm{L}$. & + & + & + & + & + & + & + & + & + & + & + & + \\
\hline Geranium palustre L. & + & + & + & + & + & + & + & + & + & + & + & + \\
\hline Geranium pratense $\mathrm{L}$. & + & + & + & + & + & + & + & + & - & - & - & - \\
\hline Geum rivale $\mathrm{L}$. & + & + & + & + & + & + & + & + & + & + & + & + \\
\hline Inula salicina $\mathrm{L}$. & + & + & + & + & + & + & + & + & + & + & + & + \\
\hline Iris sibirica $\mathrm{L}$. & + & - & - & + & + & + & - & - & - & + & - & + \\
\hline Leucanthemum vulgare Lam. & + & + & + & + & + & + & - & - & + & + & + & + \\
\hline Lotus corniculatus L. & + & + & + & - & + & + & - & - & + & + & + & + \\
\hline Lychnis flos-cuculi $\mathrm{L}$. & + & + & + & + & + & + & + & + & + & + & + & + \\
\hline Lysimachia nummularia L. & + & + & + & + & + & + & + & + & + & + & + & + \\
\hline Lysimachia vulgaris $\mathrm{L}$. & + & + & + & + & + & + & + & + & + & + & + & + \\
\hline Lythrum salicaria L. & + & + & + & + & + & + & + & + & + & + & + & + \\
\hline Mentha longifolia (L.) L. & + & + & + & + & + & + & + & + & + & + & + & + \\
\hline Polygonum bistorta L. & + & + & + & + & - & - & - & + & - & - & - & - \\
\hline Potentilla erecta (L.) Raeusch. & + & + & + & + & + & + & + & + & + & + & + & + \\
\hline Ranunculus acris L. & + & + & - & - & + & - & - & - & + & + & - & + \\
\hline Rumex acetosa $\mathrm{L}$. & + & + & + & + & + & + & + & + & - & - & - & - \\
\hline Sanguisorba officinalis L. & + & + & + & + & + & + & + & + & + & + & + & + \\
\hline Selinum carvifolia $($ L.) L. & + & + & + & + & + & + & + & + & + & + & + & + \\
\hline Serratula tinctoria $\mathrm{L}$. & + & + & + & + & + & + & + & + & + & + & + & + \\
\hline Solidago canadensis L. & + & + & + & + & + & + & + & + & + & + & + & + \\
\hline Succisa pratensis Moench. & + & + & + & + & + & + & + & + & + & + & + & + \\
\hline Valeriana officinalis L. & + & + & + & + & + & + & + & + & + & + & + & + \\
\hline Total & 34 & 33 & 32 & 32 & 31 & 31 & 27 & 28 & 26 & 28 & 25 & 26 \\
\hline
\end{tabular}


Performed observations showed that 22 taxa appeared in all-sized subplots in all patches, 10 species occurred in all-sized subplots in at least one study site, while two taxa recruited in the different-sized gaps depending of patch (Table 2). In total,14 species showed positive correlation between area of opening and offspring number, 17 taxa demonstrated negative relationship, while 3 taxa presented positive or negative correlation depending on the patch. The values of
Spearman coefficient ranged from -0.78 to 0.78 (Table 3 ). The majority of taxa presenting strong positive correlation formed hypogeogenous stems with substantial lateral growth, considerable number of daughter ramets, as well as short lifespan of shoots. On the other hand, taxa with strong negative relationship formed epigeogenous stems with slight lateral growth, as well as low offspring number (Table 4).

Table 3

The coefficient of correlation between gap size and proportional number of seedlings of particular species in the sites dominated by small meadow species (Patch ES), prevailed by tall-growing perennials (Patch MS), as well as overgrown by large-tussock species and shrub-willows (Patch LS) in the years 2011 and 2012.

The asterisks mean the significant values of Spearman coefficient at the level 0.05.

\begin{tabular}{|c|c|c|c|}
\hline Species & Patch ES & Patch MS & Patch LS \\
\hline Achillea millefolium $\mathrm{L}$. & $0.78^{*}$ & $0.43^{*}$ & $0.38^{*}$ \\
\hline Filipendula ulmaria (L.) Maxim. & $0.56^{*}$ & $0.35^{*}$ & $0.40^{*}$ \\
\hline Leucanthemum vulgare Lam. & $0.32 *$ & $0.59 *$ & 0.06 \\
\hline Lysimachia vulgaris L. & $0.51 *$ & $0.34^{*}$ & 0.22 \\
\hline Cirsium arvense (L.) Scop. & 0.14 & $0.39 *$ & $0.45^{*}$ \\
\hline Galium boreale L. & 0.00 & $0.42 *$ & $0.31 *$ \\
\hline Lysimachia nummularia $\mathrm{L}$. & 0.34 & 0.03 & 0.38 \\
\hline Iris sibirica $\mathrm{L}$. & 0.30 & $0.46^{*}$ & 0.29 \\
\hline Lotus corniculatus L. & 0.26 & $0.44 *$ & 0.14 \\
\hline Geum rivale $\mathrm{L}$. & $0.43^{*}$ & 0.16 & 0.09 \\
\hline Solidago canadensis L. & $0.42 *$ & 0.26 & 0.22 \\
\hline Galium verum $\mathrm{L}$. & $0.41 *$ & 0.26 & 0.03 \\
\hline Cirsium rivulare (Jacq.) All. & 0.28 & 0.13 & 0.27 \\
\hline Mentha longifolia (L.) L. & 0.01 & 0.01 & 0.07 \\
\hline Dianthus superbus L. & -0.05 & 0.16 & 0.10 \\
\hline Ranunculus acris L. & 0.04 & -0.14 & 0.20 \\
\hline Valeriana officinalis $\mathrm{L}$. & 0.25 & -0.18 & 0.21 \\
\hline Serratula tinctoria $\mathrm{L}$. & -0.09 & -0.01 & -0.12 \\
\hline Centaurea jacea $\mathrm{L}$. & -0.11 & - & - \\
\hline Polygonum bistorta $\mathrm{L}$. & -0.14 & -0.30 & - \\
\hline Succisa pratensis Moench. & -0.28 & -0.25 & -0.17 \\
\hline Rumex acetosa $\mathrm{L}$. & -0.27 & $-0.32 *$ & - \\
\hline Caltha palustris $\mathrm{L}$. & $-0.39 *$ & -0.13 & - \\
\hline Filipendula vulgaris Moench. & $-0.54 *$ & -0.17 & - \\
\hline Geranium pratense $\mathrm{L}$. & $-0.55^{*}$ & -0.29 & - \\
\hline Cruciata glabra (L.) Erhend. & $-0.56^{*}$ & -0.18 & -0.25 \\
\hline Geranium palustre L. & $-0.49 *$ & $-0.38 *$ & -0.22 \\
\hline Lychnis flos-cuculi $\mathrm{L}$. & $-0.42 *$ & $-0.36^{*}$ & -0.22 \\
\hline Inula salicina $\mathrm{L}$. & $-0.38 *$ & -0.18 & $-0.51^{*}$ \\
\hline Betonica officinalis L. (Trevis) & $-0.51 *$ & $-0.33 *$ & -0.05 \\
\hline Potentilla erecta (L.) Raeusch. & -0.23 & $-0.37 *$ & $-0.51^{*}$ \\
\hline Sanguisorba officinalis L. & $-0.74 *$ & $-0.78 *$ & -0.28 \\
\hline Selinum carvifolia (L.) L. & $-0.33 *$ & $-0.40 *$ & $-0.31^{*}$ \\
\hline Lythrum salicaria $\mathrm{L}$. & $-0.53 *$ & $-0.51 *$ & $-0.65^{*}$ \\
\hline
\end{tabular}


Table 4

Comparisons of life history traits related to clonal growth according to [26] in species appearing in seedling pool. Species are ordered according to list of species presented in Table 3.

\begin{tabular}{|c|c|c|c|c|}
\hline Species & $\begin{array}{l}\text { Clonal growth organ } \\
\text { (CGO) }\end{array}$ & $\begin{array}{c}\text { Lateral } \\
\text { spread }[\mathrm{m} / \text { year }]\end{array}$ & $\begin{array}{l}\text { Number of offsprings } \\
\text { per parent shoot per year }\end{array}$ & $\begin{array}{c}\text { Lifespan of } \\
\text { a shoot [years] }\end{array}$ \\
\hline Achillea millefolium $\mathrm{L}$. & Hypogeogenous stems & $>0.25$ & $2-10$ & 2 \\
\hline Filipendula ulmaria (L.) Maxim. & Hypogeogenous stems & $0.01-0.25$ & $2-10$ & 1 \\
\hline Leucanthemum vulgare Lam. & Epigeogenous stems & $0.01-0.25$ & 1 & 2 \\
\hline Lysimachia vugaris $\mathrm{L}$. & Hypogeogenous stems & $0.01-0.25$ & $2-10$ & 1 \\
\hline Cirsium arvense (L.) Scop. & Roots with adventitious buds & $>0.25$ & $2-10$ & 1 \\
\hline Galium boreale L. & Hypogeogenous stems & $0.01-0.25$ & $2-10$ & 1 \\
\hline Lysimachia nummularia L. & Horizontal above ground stems & $0.01-0.25$ & $2-10$ & 1 \\
\hline Iris sibirica $\mathrm{L}$. & Epigeogenous stems & $<0.01$ & 1 & 2 \\
\hline Lotus corniculatus L. & Root-splitters & $<0.01$ & $2-10$ & 1 \\
\hline Geum rivale $\mathrm{L}$. & Epigeogenous stems & $0.01-0.25$ & $<1$ & 1 \\
\hline Solidago canadensis L. & Hypogeogenous stems & $0.01-0.25$ & $2-10$ & 1 \\
\hline Galium verum $\mathrm{L}$. & Hypogeogenous stems & $0.01-0.25$ & 1 & 1 \\
\hline Cirsium rivulare (Jacq.) All. & Epigeogenous stems & $0.01-0.25$ & 1 & 2 \\
\hline Mentha longifolia (L.) L. & Hypogeogenous stems & $0.01-0.25$ & $2-10$ & 1 \\
\hline Dianthus superbus L. & Hypogeogenous stems & $<0.01$ & 1 & 2 \\
\hline Ranunculus acris $\mathrm{L}$. & Epigeogenous stems & $<0.01$ & 1 & 2 \\
\hline Valeriana officinalis L. & Hypogeogenous stems & $0.01-0.25$ & 1 & 2 \\
\hline Serratula tinctoria $\mathrm{L}$. & Epigeogenous stems & $<0.01$ & 1 & 2 \\
\hline Centaurea jacea $\mathrm{L}$. & Hypogeogenous stems & $<0.01$ & 1 & 1 \\
\hline Polygonum bistorta L. & Epigeogenous stems & $<0.01$ & $<1$ & 1 \\
\hline Succisa pratensis Moench. & Epigeogenous stems & $<0.01$ & $<1$ & 1 \\
\hline Rumex acetosa $\mathrm{L}$. & Epigeogenous stems & $<0.01$ & 1 & 2 \\
\hline Caltha palustris $\mathrm{L}$. & Epigeogenous stems & $<0.01$ & 1 & 2 \\
\hline Filipendula vulgaris Moench. & Epigeogenous stems & $<0.01$ & 1 & 2 \\
\hline Geranium pratense $\mathrm{L}$. & Epigeogenous stems & $<0.01$ & 1 & 2 \\
\hline Cruciata glabra (L.) Erhend. & Hypogeogenous stems & $0.01-0.25$ & 1 & 1 \\
\hline Geranium palustre L. & Epigeogenous stems & $<0.01$ & 1 & 2 \\
\hline Lychnis flos-cuculi $\mathrm{L}$. & Epigeogenous stems & $0.01-0.25$ & $2-10$ & 2 \\
\hline Inula salicina $\mathrm{L}$. & Hypogeogenous stems & $0.01-0.25$ & 1 & 1 \\
\hline Betonica officinalis L. (Trevis) & Epigeogenous stems & $<0.01$ & $<1$ & 1 \\
\hline Potentilla erecta (L.) Raeusch. & Epigeogenous stems & $<0.01$ & $<1$ & 1 \\
\hline Sanguisorba officinalis L. & Epigeogenous stems & $<0.01$ & $<1$ & 1 \\
\hline Selinum carvifolia (L.) L. & Epigeogenous stems & $<0.01$ & 1 & 2 \\
\hline Lythrum salicaria $\mathrm{L}$. & Epigeogenous stems & $<0.01$ & $<1$ & 1 \\
\hline
\end{tabular}

\section{DISCUSSION}

\section{The influence of habitat conditions on abundance of species and seedlings}

The obtained results show that the number of species and seedlings in patch dominated by small meadow taxa is greater than in patches prevailed by macroforbs and overgrown by macroforbs and shrubs are consistent with previous observations performed in Molinietum- caeruleae meadows [7]. Similar phenomenon was observed in Cirsietum rivulare meadows being in courseofsuccession [27-29]. The abovementioned authors found much weaker recruitment process in patches overgrown by shrub-willows or prevailed by large-tussock sedges, than in patches dominated by low-growing herbs. Furthermore, the decrease of species and seedling number in semi-natural grasslands along the successional gradient was found by V and vik and Goldberg [30]. 
The observed decrease of number of species and seedlings in the patches representing mid- and latesuccessional stages might be caused by the prolonged periods of spring flooding. The increase of water table might suppress the seed germination. Such phenomenon was repeatedly observed in several wetland taxa [3134]. The abovementioned authors argued that the suppression of germination may be due to increased anaerobic metabolism, which could damage diaspore through the buildup of toxic materials. Moreover, the immersion contributes to slow diffusion rates of gases hampering oxygen supply to roots and reducing respiration and photosynthesis rates in submerging plants [35]. The inhibition of growth and ultimately death in waterlogging conditions were observed by $\mathrm{Fr}$ a s e $\mathrm{r}$ and $\mathrm{K}$ a r n e $\mathrm{z}$ is [36], as well as Franczak and $\mathrm{Czarnecka}$ [37]. On the other hand, the experiments of K o t ow s k i et al. $[38,39]$ brought evidence, that the high water level usually hampers establishment of seedlings of wetland taxa in a lesser extent, than the darkness. Taking into account the abovementioned findings, it might be assumed that the diminishing abundance of species and seedlings observed in patches with rising height of standing vegetation might be due to the increasing light attenuation by adjacent plants rather than flooding.

Simultaneously, it should be added that the noted diminishing colonization of gaps in successive sites might be a consequence of root competition. So far, several authors observed that the growing density of root system of surrounding vegetation leads to the increasing nutrient uptake that may create local resource depletion zones. Such phenomenon contributes to inhibition of seedling establishment of herbaceous plants [40,41], shrubs [42] and trees [43].

\section{The species diversity}

\section{in the different-sized gaps in each patch}

As expected the species composition in subplots was similar regardless of their dimensions. Such phenomenon suggests that gaps act the role of remarkably efficient "seed traps" and the safe sites for seedling recruitment. Simultaneously, it should be pointed out that performed studies are not consistent with observations of $\mathrm{V}$ a n d vik [44] carried out in alpine grasslands in course of succession. The aforementioned author argued that gaps of different area are filled with diverse assemblages of species. Also, the observations of herbaceous ground vegetation in artificially-created gaps in a managed beech forest brought evidence that some taxa appeared in large gaps only, whilst the others recruited in small openings $[45,46]$. Moreover, it is worth to notice that similar phenomenon was observed in the seedlings pool of trees in temperate forest [47]. Also, Fahey and Puettmann [48] showed, that understorey plant community composition differed significantly between large and small openings. Fur- thermore, the diverse set of species within differentsized gaps was also observed in numerous tropical forest ecosystems [49].

\section{The correlation between gap size and number of seedlings of particular species}

Despite of similarity in floristic composition among openings, the obtained results did not uphold the null hypothesis and have showed, that many species present a positive correlation between gap dimensions and seedling number. The performed observations are consistent with the observations of colonization of different-sized openings by seedlings of Cirsium arvense [50], Solidago canadensis [51,52], as well as Iris sibirica [53].

Simultaneously, it should be added that the results of present investigations showing that Dianthus superbus may present positive correlation in some habitats and a negative relationship in the other ones, are not consistent with previous findings that regardless of patch character absolute number of generative offsprings increases with augmentation of gap area [54].

The obtained results documented that numerous species show a negative relationship between opening dimensions and the number of seedlings. The performed investigations support the studies of Le p $\breve{s}$ [55], who has found greater recruitment of Sanguisorba officinalis and Betonica officinalis in abandoned sites than in mowed ones. The microsite conditions in unmanaged meadows might resemble these ones observed in small openings because of close vicinity of adult plants occurring in existing vegetation. The adjacent mature individuals protect the seedlings from unfavorable factors such as wind and drought but on the other hand they are strong competitors for nutrients, water and light. Such phenomenon isknown as the "nurse effect" [56].The site conditions in mowed patches might be quite similar to occurring in larger openings, where the competition for resources is reduced but seedlings are exposed to unfavorable abiotic conditions, as well as the herbivore activity. Simultaneously, it should be noticed that, contrary to my findings Lepš [55] has documented a positive relationship between intensity of management and recruitment of Potentilla erecta and Selinum carvifolia. Similar phenomenon was noted by $\mathrm{Van}$ der $\mathrm{Meer}$ et al. [57], who claimed that the probability of establishment of Succisa pratensis seedlings in traditionally managed meadows is much greater than in abandoned sites.

\section{The relationship between opening size and recruitment of taxa adapted to the fast and slow clonal spread}

Presented findings showed that species showing positive correlation between seedling abundance and gap size are characterized by traits allowing rapid 
colonization of open habitat. The creation of hypogeogenous stems enables protection of meristems from destruction due to mechanical damage mainly from animal trampling and digging. The substantial vegetative growth and considerable number of daughter ramets enable also exploration of large gaps and placing descendants in favorable microhabitats, whereas short lifespan of shoots contributes to their fast turnover in large uncrowded places. The formation of epigeogenous stems by taxa showing negative relationship between offspring recruitment and gap dimensions might be connected with low risk of damage of adventitious buds in small openings. The slight values of lateral spread and low number of vegetative offsprings might be linked with restrictions in biomass production in small openings, while the long-lived ramets allow the duration of individuals in small places.

Performed studies support previous observations on the influence of disturbance intensity on recruitment of species with different parameters of selected life history traits relevant to clonality in $\mathrm{Mo}$ linietum caeruleae meadows [58]. The aforementioned author stated that abundance of taxa forming underground clonal growth organs, with considerable vegetative growth, high production of daughter ramets, short lifespan of shoots and not enduring genet integration increased gradually and significantly with growing disturbance gradient. Moreover, the increasing frequency of plants with high vegetative spread in gaps left after moderate and strong disturbances was observed in abandoned grasslands [59,60], mountain pastures [61], as well as old fields $[62,63]$.

\section{Implications for meadow conservation}

In light of performed studies it may be stated that the removal of plant canopy and litter leads to the greatest seedling appearance in site representing early successional stage. However, the creation of gaps in places representing mid- and late-successional stages might also contribute to increase of recruitment rates. The creation of different-sized gaps seems to be a very effective way for conservation of Molinietum caeruleae meadows. This treatment assures the increase of offspring number of both: taxa showing a positive and a negative correlation between seedling abundance and gap area. The appearance of such species adapted to fast and slow habitat colonization (respectively) assures the taxa heterogeneity, particularly important in the course of succession.

\section{REFERENCES}

1. Harper JL, Williams JT, Sagar GR. The behaviour of seeds in soil: I. The heterogeneity of soil surfaces and its role in determining the establishment of plants from seed. J Ecol. 1965; 53(2): 273. http://dx.doi. org/10.2307/2257975

2. S ou s a W P. The role of disturbance in natural communities. Ann Rev Ecol Syst. 1984; 15(1): 353-391. http://dx. doi.org/10.1146/annurev.es.15.110184.002033

3. Fenner M, Thompson K. The ecology of seeds. Cambridge: Cambridge University Press; 2005.

4. Qing Li Z, Bogaert J, Nijs I. Gap pattern and colonization opportunities in plant communities: effects of species richness, mortality, and spatial aggregation. Ecography. 2005; 28(6): 777-790. http://dx.doi.org/10.1111/j. 2005.0906-7590.04261.x

5. Erikss on Ĺ, Eriksson O. Seedling recruitment in semi-natural pastures: the effects of disturbance, seed size, phenology and seed bank. Nord J Bot. 1997; 17(5): 469482. http://dx.doi.org/10.1111/j.1756-1051.1997.tb00344.x

6. Burke MJW, Grime JP. An experimental study of plant community invasibility. Ecology. 1996; 77(3): 776. http://dx.doi.org/10.2307/2265501

7. Kostrakiew i c z K. The effect of gaps size on colonization process in Molinietum caeruleae meadows with different habitat conditions. Pol J Ecol. 2011; 59(4): 677-686.

8. Foster S, Janson $\mathrm{CH}$. The relationship between seed size and establishment conditions in tropical woody plants. Ecology. 1985; 66(3): 773. http://dx.doi.org/10. 2307/1940538

9. U $1 \mathrm{ft} \mathrm{L} \mathrm{H}$. The effect of seed mass and gap size on seed fate of tropical rain forest tree species in Guyana. Plant Biol. 2004; 6(2): 214-221. http://dx.doi.org/10.1055/s-2004-815736

10. Marthews TR, Mullins CE, Dalling JW, Burslem DFRP. Burial and secondary dispersal of small seeds in a tropical forest. J Trop Ecol. 2008; 24(06): 595. http://dx.doi.org/10.1017/S026646740800535X

11. Williams RJ. Gap dynamics in subalpine heathland and grassland vegetation in south-eastern Australia. J Ecol. 1992; 80(2): 343. http://dx.doi.org/10.2307/2261016

12. Kot a n e n PM. Effect of gap area and shape on recolonization by grassland plants with differing reproductive strategies. Can J Bot. 1997; 75(2): 352-361.

13. Fuller RM. The changing extent and conservation interest of lowland grasslands in England and Wales: a review of grassland surveys 1930-1984. Biol Conserv. 1987; 40(4): 281-300. http://dx.doi.org/10.1016/0006-3207(87)90121-2

14. Green BH. Agricultural intensification and the loss of habitat, species and amenity in British grasslands: a review of historical change and assessment of future prospects+. Grass Forage Sci. 1990; 45(4): 365-372. http://dx.doi.org/ 10.1111/j.1365-2494.1990.tb01961.x

15. Prach K. Vegetational changes in a wet meadow complex, South Bohemia, Czech Republic. Folia Geobot. 1993; 40(1): 1-13. http://dx.doi.org/10.1007/BF02853197

16. Joyce CB, Wade PM, editors. European wet grasslands: biodiversity, management, and restoration. Chichester: John Wiley; 1998. (Landscape ecology series).

17. Muller S. Diversity of management practices required to ensure conservation of rare and locally threatened plant 
species in grasslands: a case study at a regional scale (Lorraine, France). Biodivers Conserv. 2002; 11(7): 1173-1184. http://dx.doi.org/10.1023/A:1016049605021

18. Zarzycki K. Wilgotne ląki w okolicy Czernichowa i potrzeba ich ochrony. Ochr Przyr. 1958;25:49-59.

19. Dubiel E. Mapa roślinności aktualnej Krakowa. Zesz Nauk UJ Pr Bot. 1991; 22: 121-133.

20. Dubiel E. Łąki Krakowa. I. Klasa Molinio-Arrhenatherea. Stud Ośrodka Dok Fizjogr. 1996; 24: 145-171.

21. Cs a p odý V. Keimlingsbestimmungsbuch der Dikotyledonen. Budapest: Akadémiai Kiadó; 1968.

22. Muller FM. Seedlings of the North-Western European lowland. A flora of seedlings. Wageningen: Dr. W. Junk B.V. Publishers; 1978.

23. Mirek Z, Piękoś-Mirkowa H, Zając A, $\mathrm{Z}$ ając M. Flowering plants and pteridophytes of Poland. A checklist. Krytyczna lista roślin naczyniowych Polski. Cracow: W. Szafer Institute of Botany, Polish Academy of Sciences; 2002.

24. Klimesova J, Latzel V, de Bello F, van Groenendael JM. Plant functional traits in studies of vegetation changes in response to grazing and mowing: towards a use of more specific traits. Preslia. 2008; 80(3): 245-253.

25. Kli mešova J, K li meš L. CLO-PLA 3 - a database of clonal growth in plants [Internet]. 2013 [cited 2014 Oct 31]; Available from: http://clopla.butbn.cas.cz

26. Klimešová J, de Bello F. CLO-PLA: the database of clonal and bud bank traits of Central European flora. J Veg Sci. 2009; 20(3): 511-516. http://dx.doi.org/10.1111/ j.1654-1103.2009.01050.x

27. B orkowska L. Patterns of seedling recruitment in experimental gaps on mosaic vegetation of abandoned meadows. Acta Soc Bot Pol. 2004; 73(4): 343-350. http://dx.doi. org/10.5586/asbp.2004.045

28. B orkowska L. Wzorce rekrutacji siewek gatunków klonalnych w zbiorowisku niekoszonej łąki Cirsietum rivularis Ralski 1931. Wyniki badań eksperymentalnych. Phytocoenosis (N.S.). Arch Geobot. 2004; 10: 1-71.

29. Falińs ka K. Alternative pathways of succession species turnover patterns in meadows abandoned for 30 years. Phytocoenosis (N.S.). Arch Geobot. 2003; 9: 1-100.

30. Vandvik V, Goldberg DE. Sources of diversity in a grassland metacommunity: quantifying the contribution of dispersal to species richness. Am Nat. 2006; 168(2): 157167. http://dx.doi.org/10.1086/505759

31. Van der Valk AG, Davis CB. The role of seed banks in the vegetation dynamics of prairie glacial marshes. Ecology. 1978; 59(2): 322. http://dx.doi.org/10.2307/1936377

32. Guo Y, Shelton MG, Lockhart BR. Effects of flood duration and season on germination of black, cherrybark, northern red, and water oak acorns. New For. 1998; 5(1): 69-76.

33. Walls RL, Wardrop DH, Brooks RP. The impact of experimental sedimentation and flooding on the growth and germination of floodplain trees. Plant Ecol. 2005; 176(2): 203-213. http://dx.doi.org/10.1007/s11258-004-0089-y
34. Pérez-Ramos IM, Marańón T. Effects of waterlogging on seed germination of three Mediterranean oak species: ecological implications. Acta Oecol. 2009; 35(3): 422-428. http://dx.doi.org/10.1016/j.actao.2009.01.007

35. Voesenek LACJ, Colmer TD, Pierik R, Millenaar FF, Peeters AJM. How plants cope with complete submergence. New Phytol. 2006;170(2):213-226. http://dx.doi.org/10.1111/j.1469-8137.2006.01692.x

36. Fraser LH, Karnezis JP. A comparative assessment of seedling survival and biomass accumulation for fourteen wetland plant species grown under minor water-depth differences. Wetlands. 2005; 25(3): 520-530. http://dx.doi. org/10.1672/0277-5212(2005)025[0520:ACAOSS]2.0.CO;2

37. Franczak M, Czarnecka B. Unitary and iterative growth of clonal species individuals: significance for the spatial structure and the dynamics of population abundance. Ann UMCS Biol. 2009; 64(2): 9-21. http://dx.doi.org/10. 2478/v10067-010-0010-0

38. Kotowski W, van Andel J, van Diggelen R, Hogendorf J. Responses of fen plant species to groundwater level and light intensity. Plant Ecol. 2001; 155(2): 147-156. http://dx.doi.org/10.1023/A:1013214716842

39. Kotowski W, Beauchard O, Opdekamp W, Meire P, van Diggelen R. Waterlogging and canopy interact to control species recruitment in floodplains: interacting factors in floodplain species recruitment. Func Ecol. 2010; 24(4): 918-926. http://dx.doi.org/10.1111/j. 1365-2435.2009.01682.x

40. Aguiar MR, Soriano A, Sala OE. Competition and facilitation in the recruitment of seedlings in Patagonian steppe. Func Ecol. 1992; 6(1): 66. http://dx.doi.org/ $10.2307 / 2389772$

41. Aguiar MR, Sala OE, Aguiar MR. Competition, facilitation, seed distribution and the origin of patches in a Patagonian steppe. Oikos. 1994; 70(1): 26. http://dx. doi.org/10.2307/3545695

42. Shiponeni NN, Carrick PJ, Allsopp N, Hoffman MT. Effects of root competition and soils on seedling establishment at the ecotone between an arid grassland and succulent shrubland in South Africa. J Veg Sci. 2014; 25(2): 402-410. http://dx.doi.org/10.1111/jvs.12082

43. Walker LR, Chapin FS. Physiological controls over seedling growth in primary succession on an Alaskan Floodplain. Ecology. 1986; 67(6): 1508. http://dx.doi. org/10.2307/1939082

44. Vandvik V. Gap dynamics in perennial subalpine grasslands: trends and processes change during secondary succession. J Ecol. 2004; 92(1): 86-96. http://dx.doi. org/10.1111/j.1365-2745.2004.00842.x

45. Degen T, Devillez F, Jacquemart A-L. Gaps promote plant diversity in beech forests (Luzulo-Fagetum), North Vosges, France. Ann Sci. 2005; 62(5): 429-440. http://dx.doi.org/10.1051/forest:2005039

46. Kelemen K, Mihók B, Gálhidy L, Standovár T. Dynamic response of herbaceous vegetation to gap opening in a Central European beech stand. Silva Fenn. 2012; 46(1): 53-65. 
47. Kern CC, Montgomery RA, Reich PB, Strong TF. Canopy gap size influences niche partitioning of the ground-layer plant community in a northern temperate forest. J Plant Ecol. 2013; 6(1): 101-112. http://dx. doi.org/10.1093/jpe/rts016

48. Fahey RT, Puettmann KJ. Ground-layer disturbance and initial conditions influence gap partitioning of understorey vegetation. J Ecol. 2007; 95(5): 1098-1109. http://dx.doi.org/10.1111/j.1365-2745.2007.01283.x

49. Dupuy JM, Chazdon RL. Interacting effects of canopy gap, understory vegetation and leaf litter on tree seedling recruitment and composition in tropical secondary forests. Ecol Man. 2008; 255(11): 3716-3725. http://dx.doi. org/10.1016/j.foreco.2008.03.021

50. Gálhidy L, Mihók B, Hagyó A, Rajkai K, $\mathrm{S}$ t a nd ovár T. Effects of gap size and associated changes in light and soil moisture on the understorey vegetation of a Hungarian beech forest. Plant Ecol. 2006; 183(1): 133-145. http://dx.doi.org/10.1007/s11258-005-9012-4

51. Goldberg DE, Werner PA. The effects of size of opening in vegetation and litter cover on seedling establishment of goldenrods (Solidago spp.). Oecologia. 1983; 60(2): 149-155. http://dx.doi.org/10.1007/BF00379516

52. Eckstein RL, Ruch D, Otte A, Donath TW. Invasibility of a nutrient-poor pasture through resident and non-resident herbs is controlled by litter, gap size and propagule pressure. PLoS ONE. 2012; 7(7): e41887. http:// dx.doi.org/10.1371/journal.pone.0041887

53. Kostrakiewicz-Gierałt K. The impact of neighbourhood and gap character on seedling recruitment of Trollius europaeus L. and Iris sibirica L. in Molinietum caeruleae meadows. Biodiv Res Conserv. 2012; 28(1): 37 44. http://dx.doi.org/10.2478/v10119-012-0026-1

54. Kostrakiewicz-Gierałt K. The effect of neighbouring plant height, disturbance level and gap size on spontaneous recruitment of small- and large-seeded species in Molinietum caeruleae meadows. Pol J Ecol. 2014; 62(2): 259-276.

55. L ep š J. Nutrient status, disturbance and competition: an experimental test of relationships in a wet meadow. J Veg Sci. 1999; 10(2): 219-230. http://dx.doi.org/10.2307/3237143

56. Van der Meer S, Dahlgren JP, Mildén M, Ehrlén J. Differential effects of abandonment on the demography of the grassland perennial Succisa pratensis. Popul Ecol. 2014; 56(1): 151-160. http://dx.doi.org/10.1007/ s10144-013-0400-7

57. Van der Meer S, Dahlgren JP, Milden M, Ehrien J.P Differential effects of abandonment on the dermography of the grassland perennial succisa pratencis. Popul. Ecol. 2013; 26(1): 151-169. http://dx.doi. org/10.1007/s10144-013-0400-7

58. Kostrakiewicz-Gierałt K. The impact of disturbance gradient on recruitment of clonal plant species in Molinietum caeruleae meadows. Pol J Ecol. 2013; 61(3): 519-533.

59. McIntyre S, Lavorel S. Livestock grazing in subtropical pastures: steps in the analysis of attribute response and plant functional types. J Ecol. 2001; 89(2): 209-226. http://dx.doi.org/10.1046/j.1365-2745.2001.00535.x

60. Kahmen S, Poschlod P. Effects of grassland management on plant functional trait composition. Agric Ecosyst Env. 2008; 128(3): 137-145. http://dx.doi.org/10.1016/j. agee.2008.05.016

61. Kohler F, Gillet F, Gobat J-M, Buttler A. Effect of cattle activities on gap colonization in mountain pastures. Folia Geobot. 2006; 41(3): 289-304. http://dx.doi. org/10.1007/BF02904943

62. Lavorel S, Touzard B, Lebreton J-D, Clément B. Identifying functional groups for response to disturbance in an abandoned pasture. Acta Oecol. 1998; 19(3): 227-240. http://dx.doi.org/10.1016/S1146609X(98)80027-1

63. Lavorel S, Rochette C, Lebreton J-D. Functional groups for response to disturbance in mediterranean old fields. Oikos. 1999; 84(3): 480. http://dx.doi. org/10.2307/3546427

\section{Wpływ stadium sukcesji i wielkości luk na rekrutację gatunków klonalnych w płatach zarastających łąk trzęślicowych}

\section{Streszczenie}

W wielu zbiorowiskach roślinnych o zwartej pokrywie roślinnej zaburzenia powstałe na skutek abiotycznych i biotycznych czynników przyczyniają się do powstania luk uważanych za bezpieczne miejsca do kiełkowania. Luki charakteryzują się wieloma cechami, z których wielkość jest powszechnie uważana za najważniejszą. Badania rekrutacji siewek gatunków klonalnych w lukach o odmiennych rozmiarach były prowadzone w latach 2011-2012 w płatach łąk trzęslicowych Molinietum caeruleae reprezentujących zróżnicowane stadia sukcesji wtórnej i zdominowanych przez różne gatunki. Płat ES reprezentujący początkowe stadium zarastania był zdominowany przez niewielkie gatunki łąkowe, w Płacie MS reprezentującym pośrednie stadium przeważały wysokie ziołorośla, natomiast Płat LS reprezentujący stadium końcowe był zarośnięty przez ziołorośla i krzewiaste gatunki wierzb. Całkowita liczba gatunków i siewek na kolejnych powierzchniach badawczych stopniowo malała. Zjawisko to może być związane z coraz dłuższym okresem wiosennych podtopień, spadkiem dostępności światła lub zwiększającym się wykorzystaniem zasobów przez gatunki obecne w pokrywie roślinnej. Prawie wszystkie gatunki prezentujące pozytywną korelację pomiędzy liczbą siewek a rozmiarem luk cechują się znacznym wzrostem wegetatywnym i dużą produkcją ramet potomnych umożliwiających szybką kolonizację zasiedlonego miejsca. Większość gatunków wykazujących negatywną 
korelację charakteryzuje się wolnym wzrostem wegetatywnym oraz wytwarzaniem niewielkiej liczby długotrwałych ramet potomnych. W świetle przeprowadzonych badań można stwierdzić, że zaburzenia w zwartej pokrywie roślinnej i ściółce mogą przyczynić się do zachowania łąk trzęślicowych. Ponadto tworzenie luk o zróżnicowanych rozmiarach wydaje się szczególnie ważne ze względu na podtrzymanie różnorodności gatunków klonalnych, zwłaszcza w zaawansowanych stadiach sukcesji.

Handling Editor: Elżbieta Weryszko-Chmielewska

This is an Open Access digital version of the article distributed under the terms of the Creative Commons Attribution 3.0 License (creativecommons.org/licenses/by/3.0/), which permits redistribution, commercial and non-commercial, provided that the article is properly cited.

CThe Author(s) 2014 Published by Polish Botanical Society 
